\title{
THE EFFECT OF ARGENTINE STEM WEEVIL ON PASTURE COMPOSITION IN CANTERBURY
}

\author{
S.L. GOLDSON and T.E.T. TROUGHT \\ Research Division, MAF, Lincoln
}

Summary

Small plots in a two year old mixed ryegrass ('Grasslands Manawa' Lolium multiflorum $x$ perenne) and white clover (Trifolium repens) pasture were treated with insecticide at regular intervals over a period of 12 weeks. These maintained a significantly higher grass component than the corresponding untreated plots which became substantially clover dominant. In terms of dry matter of grass, the treated plots yielded a mean of $87.5 \mathrm{~g} / \mathrm{m}^{2}$ compared to $26.6 \mathrm{~g} / \mathrm{m}^{2}$ in the untreated. Clover yields were virtually identical in both the treated and untreated plots yielding $102 \mathrm{~g} / \mathrm{m}^{2}$ and $110 \mathrm{~g} / \mathrm{m}^{2}$ dry matter respectively. Indications were that Argentine stem weevil (Hyperodes bonariensis) was totally responsible for the clover dominance.

\section{INTRODUCTION}

Argentine stem weevil is a major pest of Graminae in Canterbury and other dry eastern parts of New Zealand. The adult weevils can cause severe losses of seedlings by destroying the emerging cotyledons. Furthermore, through their mining habit the larvae can cause loss of yield by destroying both vegetative and reproductive tillers of mature plants (Trought 1976). Losses are particularly severe in short rotation ryegrasses such as 'Grasslands Tama' (Tetraploid Lolium multiflorum), 'Grasslands Paroa' (L. multiflorum) and Manawa. Both types of damage are insidious: the former is frequently attributed to poor germination and the latter, to factors such as poor soils and drought. Indeed, it is often only when a pasture does not respond to autumn rains that the damage is recognised (Whatman 1959). Argentine stem weevil larvae are oligophagous and are only known to develop fully in Graminae. A possible effect of this can be development of clover dominant pasture by the selective destruction of the ryegrass component. This has been suggested by May (1961), Pottinger (1961) and Batten (1964). The aim of this study was to confirm these observations and to evaluate how thoroughly and rapidly a change can occur in two year old Manawa ryegrass-clover pasture in Canterbury.

\section{METHOD}

The trial was established on 10.1.77 in a two year old mixed ryegrass-clover paddock with a well established Argentine stem weevil infestation as determined by spring sampling for adults (c. $\left.280 / \mathrm{m}^{2}\right)$. It consisted of seven paired replicates of $400 \mathrm{~mm}$ $\mathrm{x} 330 \mathrm{~mm}$ plots of pasture that were protected from grazing by $300 \mathrm{~mm}$ high wire cages. One plot of each pair was treated at weekly intervals with azinphos-methyl at an equivalent rate of $2 \mathrm{~kg} / \mathrm{ha}$ to eradicate all of the weevils. In order to prevent insecticide drift a $750 \mathrm{~mm}$ high metal frame was placed around the treated plots during each application. The other plot in each pair remained untreated. After 12 weeks the sward under each cage was cut, dissected into grasses and clovers, dried and weighed.

Throughout the experiment close inspections were made to ascertain the effects of slugs and insects on the untreated plots.

Proc. 33rd N.Z. Weed and Pest Control Conf. 
Fig 1. One of the paired replicates demonstrating the elimination of grasses (left
hand side) in an untreated plot through Argentine stem weevil damage

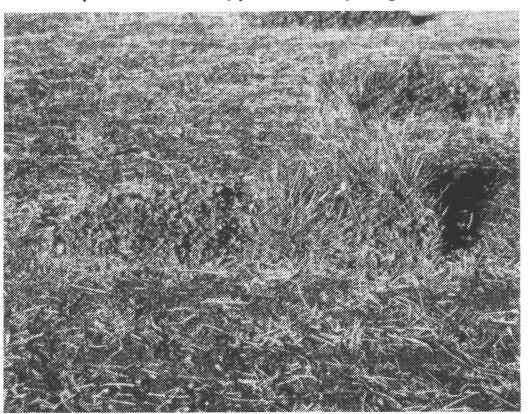

RESULTS AND DISCUSSION

The right hand plot in Fig. 1 shows how, by eliminating the insect population
rass persisted in the sward. In contrast to this the left hand plot shows clove

of dry matter of grass the insecticidally protected plots yield

mean of $87.5 \mathrm{~g} / \mathrm{m}^{2}$ compared to a significantly (P 40.01 r) reduced mean of $26.6 \mathrm{~g} / \mathrm{m}^{2}$
from the untreated. Interestingly, the dry matter yields of clover were virtually
identical: the untreated plots produced $110 \mathrm{~g} / \mathrm{m}^{2}$ compared to $102 \mathrm{~g} / \mathrm{m}^{2}$ in the treated
plots.

plots. Close examination of the grass in the untreated plots during the trial and after

cutting revealed numerous desicated grass tillers with Argentine stem weevivi larval ex
holes. These were not present in the treated plots thus supporting the contention the

the damage by weevil larvae was the major cause of the clover dominance in the
untreated plots. The possibility of the more polyphagous slugs, porina or cutworms
playing a major part can be largely eliminated in view of the equal persistence and yiel

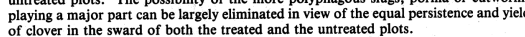

At the time of establishment of this experiment the majority of the first summer
(n)eeration Argentine stem weevi adults were reaching maturity (Goldson 1979) and

can be deduced from this that most of the damage was the outcome of the feed

Fig. 1 shows the final outcome of a very rapid reversion of mixed pasture to
clover dominance. In a matter of 12 weeks most of the grass had disappeared.

However, this may be an uncommonly rapid rate of change as the pasture surrounding

the trial cages was mob-stocked and this may have led to unusually high numbers of
weevils moving onto the plots sin search of suitable host plants. Nonetheless, the trial

clearly demonstrated that the weevil can 


\section{Pasture and Forage Crop Pests}

composition. There is no reason to believe that a similar dominance would not emerge amongst other stem weevil resistant pasture species wherever the pest is numerous; this may, for instance, go some way to explaining browntop reversion in hill country areas. On a similarly speculative note it seems possible that the relatively short life of some ryegrasses may be in part due to their high susceptibility to this pest (Kelsey 1958; Pottinger 1961; Goldson 1979) as well as genetically controlled short rotation characteristics.

\section{REFERENCES}

Batten, G.J., 1964. Control of stem weevil by management. Proc. 17th N.Z. Weed and Pest Control Conf. 157-160.

Goldson, S.L., 1979. The reproductive seasonality and morphology of Argentine stem weevil Hyperodes bonariensis Kuschel (Coleoptera: Curculionidae) and the effect of host grasses on its pre-reproductive development. Thesis, Ph.D., Lincoln College, University of Canterbury, N.Z. 250p.

Kelsey, J.M., 1958. Damage in ryegrass by Hyperodes griseus Hust. N.Z. J. Agric. Res. 1:790-795.

May, B.M., 1961. The Argentine stem weevil Hyperodes bonariensis Kuschel on pasture in Auckland. N.Z. J. Agric. Res. 4:289-297.

Pottinger, R.P., 1961. A study on the biology and economic importance of the Argentine stem weevil Hyperodes bonariensis Kuschel, in New Zealand. Thesis M. Agr. Sc., Lincoln College, University of Canterbury, N.Z. 317p.

Trought, T.E.T., 1976. Control of Argentine stem weevil in seedling ryegrass. Proc. 29th N.Z. Weed and Pest Control Conf. 203-206.

Whatman, C.P., 1959. Damage to pastures by wheat stem weevil. N.Z. J. Agric. 98:551-552. 